\title{
Scepticism and Self-Transformation in Nietzsche - On the Uses and Disadvantages of a Comparison to Pyrrhonian Scepticism
}

\section{$\underline{\text { Introduction }}$}

Pierre Hadot $(1995,272)$, Michel Foucault $(2005,28)$ and Alexander Nehamas $(1985,2000)$ have all recognised in Nietzsche a continuation of the spirit of Hellenistic philosophy, in which philosophy is not simply a theoretical enquiry but a way of life. The advantage of comparing Nietzsche to Hellenistic thinkers, such as the Pyrrhonian sceptics, is this brings us to the recognition that the same critical method that Nietzsche uses to diagnose a crisis in contemporary Europe and demonstrate the need for change also contains the possibility of bringing about that change and curing the sickness of modern man. Scepticism is part of this cure. Thus, to understand Nietzsche's statements on scepticism and the role that it plays in his philosophy we need to recognise that for Nietzsche scepticism is a practical endeavour that has an effect on those who pursue it. This suggests an important affinity with Pyrrhonian scepticism. Jessica Berry has recently explored this affinity as a way to approach Nietzsche's philosophy, and while she does not claim that Nietzsche is simply a Pyrrhonian sceptic she does argue for substantial similarities $(2011,24-25)$.

The disadvantage of approaching Nietzsche through the lens of Pyrrhonism is that it encourages a reading of Nietzsche's philosophical practice in terms of the goal of working on or perfecting a self whose fundamental character is not challenged. Of course, some Hellenistic thinkers were critical of social roles and behaviour. As A.A. Long suggests, both the Epicureans and the Stoics criticise contemporary society because it leads us to 'neglect a life in agreement with our nature.' $(2006,23)$ Nietzsche's criticisms, however, certainly from Thus Spoke Zarathustra onwards, run more deeply. For Nietzsche, the human as we know it is forged in the context of its social existence. His criticisms of modern culture, or the lack of it, and modern man, call for the destruction or 'going-under' [Untergehen] of the human as it is now. (Z Prologue 4) ${ }^{\mathrm{ii}}$ Nietzsche asks 'for what shall 'man' as a whole - no longer just one people, one race - be cultivated and bred?' (KSA 11: 37 [8]) He is interested in discovering what 'given a favourable accumulation and intensification of forces, and tasks, could be cultivated out of $m a n$ '. In order 'to prepare for great enterprises and collective experiments in discipline and breeding' he declares we need 'new philosophers' and 'men of the future' (BGE 203). Hence, while, as I shall discuss below, Nietzsche questions the idea of a unified self, the task of breeding a new type operates at the level of the individual and requires that those who are up to the task undertake a 'conscious employment of a unity of method' (BGE 210). In his mature philosophy, Nietzsche is not looking for readers who are content to work on and cultivate an existing self, but hopes to inspire a select audience to radically transform the self, and ultimately to create beings very different from the modern men he saw around him. 
That Nietzsche is concerned with a project of radical self-transformation has implications for the particular practices that he advocates, including scepticism. Firstly, we find that the practices he would have us take up do not simply work on the selves that we currently are but destroy the self as it currently exists. Hence, Zarathustra tells us 'Those who go under I love with my entire love' (Z III $12,6)$. Those engaging now in practices of self-transformation can only hope to be the ancestors of the ultimate end of Nietzsche's project of transformation. This end is the necessarily opaque figure of the overman [Übermensch], who as a being beyond what we are now, can only be hinted at from our current perspective (Z I Prologue 3,4). ${ }^{\text {iii }}$ To set humanity on a path towards the overman requires that some individuals let go of the selves they currently are and be open to experiment (Z III 25). Thus, the second important implication of Nietzsche's commitment to radical transformation is that the practices of working on the self that he advocates involve experiment. The philosophers of the future whom he calls for in Beyond Good and Evil 'will certainly be experimenters' and 'as critics of body and soul, they like to employ experiment in a new, perhaps wider, perhaps more dangerous sense.' (BGE 210) Nietzsche, therefore, maintains the need for us to explore our drives and passions in order to allow for experiment and the creation of new values and new ways of being.

If we turn to the particular example of scepticism, then any account of the role of Nietzsche's scepticism must reconcile the questioning of belief and values that a sceptical attitude requires with the need for commitment to new values. It has already been recognised in the literature that this presents a tension with Pyrrhonism. Richard Bett rightly stresses that Nietzsche would not accept a Pyrrhonian suspension of judgement given that he is ultimately concerned with the creation of values, but he does not consider Nietzsche's scepticism in terms of a practice that affects those who take it up and thus prepares them for such creation $(2000,79)$. Andreas Ur Sommer recognises that asserting one's perspectives against other interpretations is part of Nietzsche's sceptical practice, and not merely a limitation on Nietzsche's scepticism $(2006,267)$. However, his discussion of the role of scepticism is limited to combating existing values and beliefs. We need to understand how scepticism has an effect on those who practice it which enables new creation. Additionally, this underscores another fundamental difference between a Nietzschean and a Pyrrhonian Scepticism. I will argue below that for Nietzsche we cannot be truly sceptical whilst living as before and following customs because living involves valuing. While it has been noted before that the Pyrrhonian following of convention sharply contrasts to the spirit of Nietzsche's thought (Parush, 79, 535), my claim is that for Nietzsche it is incompatible with a critical scepticism than can uproot our entrenched beliefs and values. To continue to act as before fails to challenge the values that these acts instantiate, and the self that is defined by these actions and values. A transformative scepticism thus requires that we act differently. Further, as acting is a form of evaluation, acting differently means experimenting with alternative values. Hence, Nietzsche's scepticism is experimental not only because he advocates the creation of new values but because we cannot challenge existing values without experimenting with new ones. 
Comparing Nietzsche's sceptical practice to Pyrrhonian scepticism shows how distinctive Nietzsche's scepticism is. Before entering into this comparison, I want to set out the key features of Pyrrhonism, or at least the version of it that has come down to us.

\section{Pyrrhonian Scepticism}

Much of what we know of ancient Scepticism comes from the writings of Sextus Empiricus' Outlines of Scepticism and Diogenes Laertius' Lives and Opinions of Eminent Philosophers. It is Diogenes Laertius' text, which Nietzsche references in his notebooks and letters, ${ }^{\text {iv }}$ though Bett and Jessica Berry both argue that Nietzsche's knowledge of scepticism suggests his reading on ancient scepticism went beyond Diogenes, Berry arguing that Nietzsche would have been familiar with the work of Sextus Empiricus through his work on Democritus (Bett, 2000, 67; Berry, 2011, 27-28). Urs Sommer suggests there is no evidence Nietzsche read Sextus in the original but cites various surveys of Greek thought that Nietzsche did read that discuss ancient scepticism (2006, 259).v A further, late, source for Nietzsche was Victor Brochard's Les Sceptiques Grecs which he read in 1888 (Brobjer, 2008, 104). Certainly Nietzsche was aware of details of Pyrrhonian scepticism from a variety of sources.

It is Sextus Empiricus who gives us our most complete account of Pyrrhonian scepticism, so termed because he credits Pyrrho of Elis as the founder of the version of scepticism that he is presenting and advocating. I will, therefore, rely principally on his Outlines of Scepticism to sketch an account of Pyrrhonian scepticism that we can use as a counterpoint to our analysis of Nietzsche's own version of a practical scepticism.

At its core Pyrrhonian scepticism is the suspension of judgement. According to Sextus:

Scepticism is an ability to set out oppositions among things which appear and are thought in any way at all, an ability by which, because of the equipollence in the opposed objects and accounts, we come first to a suspension of judgement and afterwards to tranquillity. ( $P H$ I 8) vi

Pyrrhonian sceptics cultivate the ability to see that one account or description of something is always equally compelling as another. Thus the intellect is suspended so as neither to posit nor to reject anything because of the equipollence of the matters being investigated.' (PH I 196)

The problem this immediately raises is how we can live in this state of suspended judgement. Surely we make various judgements when we operate in the world, both practical conditional assumptions, such as not picking up hot metal if we don't want to burn our hands, and value judgements, such as it being good to avoid burning our hands. Whether Sextus is claiming that the sceptic can live without any belief is debated within the secondary literature. 
One way that sceptics may be said to have beliefs is if they believe that they have certain experiences. Whether when sceptics say, 'I am in pain', or 'I am hot', they are reporting a belief about having an experience or whether, as Jonathan Barnes claims, they simply report or avow their experiences or feelings, is not something that we need to decide for the purposes of this discussion $(1998,66)$. Even if we allow that sceptics affirm that they have experiences, if they make no judgement concerning whether these experiences are of anything, or whether they are good or bad, it is still not clear how they are to live and make practical choices. It is problematic whether appearance alone can operate as a criterion for action, as the sceptics claim it can. As Diogenes Laertius reports: 'the apparent is the Sceptic's criterion, as indeed Aenesidemus says; and so does Epicurus. Democritus, however, denied that any apparent fact could be a criterion, indeed he denied the very existence of the apparent.' (DL IX 106) ${ }^{\text {vii }}$

Michael Frede argues we should not restrict the Pyrrhonians' beliefs to the fact that they have experiences, claiming that Sextus only rules out a certain kind of belief. On Frede's reading the beliefs denied to the sceptic are those Sextus describes in $P H$ I, 13 as 'assent to some unclear object of investigation in the sciences', but sceptics can have beliefs about things that are simply evident to us and not arrived at rationally $(1998,18)$. Against Frede, Myles Burnyeat, Barnes, and Vogt all offer alternative interpretations of $P H$ I 13 that can be reconciled with passages that imply the sceptic affirms nothing about the world (PH I 15, 24, 192). viii I will argue below that Nietzsche's scepticism is incompatible with both interpretations of Sextus' scepticism. Even if Frede is right about Sextus' intentions, however, for the purposes of assessing whether Nietzsche can be seen to be taking up a version of Pyrrhonian Scepticism, the reception of Pyrrhonian ideas in the sources he would have encountered is perhaps what is most pertinent. Contemporary opponents to Pyrrhonism took it to be impractical because it required one to live with no beliefs about the world, hence the caricature of Pyrrho taking no heed of hazards and being followed by his friends to keep him from harm's way (DL IX 62). As Diogenes Laertius reports it the dogmatic philosophers maintain that the Sceptics do away with life itself, in that they reject all that life consists in' (DL IX 104). Pyrrhonism as it was debated in the ancient world, does seem to present the practical problem of how we can live without affirming anything about the world.

Sextus was well aware of the longstanding objection that scepticism did not allow one to act. ix In response he says the sceptics: 'attending to what is apparent, live in accordance with everyday observances, without holding opinions - for we are not able to be utterly inactive.' (PH I 23) They 'follow laws and customs and natural feelings, and so live without holding opinions.' ( $P H$ I 231) Or as Diogenes Laertius puts it 'we may chose a thing or shrink from a thing by habit and may observe rules and customs.' (DL IX 108) Thus, sceptics drink when they feel the impulsion of thirst, and pull their hand away from hot metal when they feel pain, without any need for a belief as to whether it is really hot. They also avoid picking up a piece of metal from the fire, following 'recollective signs' ( $P H$ II 102). ${ }^{x i}$ Sceptics will get dressed in the morning and obey the law, not wander naked in the streets. Sextus allows further that they can employ the practical expertise they have acquired ( $P H$ I 24). However, as a sceptic he insists that 'we 
do not call anything good or bad with the thought that what we say is plausible rather, without holding opinions we follow ordinary life in order not to be inactive' ( $P H$ I 226). Sceptics, he claims, go along with things, in the sense of 'yielding without adherence' ( $P H$ I 230), letting themselves be guided practically without making any judgement.

What then is the advantage of acquiring the sceptical ability of withholding judgment? It is the practical concern of tranquillity. Sextus suggests that initially the sceptics examined matters that were undecided in the hope of finding the truth and thereby achieving tranquillity, but after seeing that the positions in the dispute were equipollent 'they suspended judgement, tranquillity followed as it were fortuitously, as a shadow follows a body.' (PH I 27) This description is echoed in Diogenes Laertius' Lives. 'The end to be realised they hold to be suspension of judgement, which brings with it tranquillity like a shadow.' (DL IX 107) The claim then is that the sceptics chance upon the happy accident that once one accepts that 'objects appear to us equal in respect of convincingness and lack of convincingness' (PH I 196), this brings with it tranquillity. The sceptic is still affected by physical feelings but this too is made easier by not taking them to be bad in themselves: 'those who make no determination about what is good and bad by nature neither avoid nor pursue anything with intensity; and hence they are tranquil.' (PH I 28) Thus, 'the aim of Sceptics is tranquillity in matters of opinion and moderation of feeling in matters forced upon [them].' (PH I 25)

\section{The Problem of Nietzsche's Scepticism}

Let us turn now to scepticism as it appears in Nietzsche's thought. As with many key concepts in Nietzsche's philosophy, his discussions of scepticism present us with a tension. We find both high praise and severe criticism of scepticism. On the one hand in The Anti-Christ we encounter the claim 'Great spirits [Geister] are sceptics. Zarathustra is a sceptic. The vigour of the spirit [Geistes], its freedom through strength and superior strength, is proved by scepticism.' (AC 54) ${ }^{\mathrm{xii}} \mathrm{On}$ the other, in his Untimely Meditations Nietzsche describes 'a hopeless sea of scepticism' (UT II 10), and we find in Beyond Good and Evil the assertion that 'scepticism is the most spiritual expression of a certain complex physiological condition called in ordinary language nervous debility and sickness' (BGE 208).

Jessica Berry's explanation of this tension is that it is a modern scepticism which following Descartes is fundamentally epistemological in its concerns that Nietzsche rejects, advocating instead a scepticism that is broadly Pyrrhonian in character $(2011,33-34)$.xii Certainly, Nietzsche talks about different kinds of scepticism, contrasting the weak scepticism he attacks in Beyond Good and Evil 208 to 'a new and stronger species of scepticism' (BGE 209). So we need to clarify what kind of scepticism it is that Nietzsche advocates and how it differs from the scepticism of 'nervous debility and sickness'. But is Nietzsche's stronger and healthier scepticism Pyrrhonian in character to the extent that Berry claims?

\section{$\underline{\text { Scepticism and Transformation }}$}


Any attempt to understand the nature of Nietzsche's scepticism must recognise that it has a therapeutic role in that it is in some sense aimed at making us healthy or curing a sickness. xiv Sextus claims that 'Sceptics are philanthropic and wish to cure by argument, as far as they can, the conceit and rashness of the Dogmatists.' (PH III 280) In turn, Nietzsche claims that his own philosophical journey has operated as a kind of self-cure. Describing Human all too Human, Nietzsche claims that here he was concerned with the question of the value of morality and in particular of the 'unegoistic' as deified by Schopenhauer:

against these very instincts I gave vent to an increasingly deep mistrust, a scepticism which dug deeper and deeper! Precisely here I saw the great danger to mankind its most sublime temptation and seduction temptation to what? To nothingness? - precisely here I saw the beginning of the end, standstill, mankind looking back wearily, turning its will against life, and the onset of the final sickness becoming gently, sadly manifest. (GM Preface 5)

It was, Nietzsche claims, his scepticism that cured him of the influence of Schopenhauer, allowing him to realise that Schopenhauer's philosophy was another incarnation of the ascetic ideal. His scepticism, by showing him the emptiness of this romantic ideal, had a curative effect enabling him, as he claims in Ecce Homo, to 'To look from a morbid perspective towards healthier concepts and values,' (EH Wise 1).

For Nietzsche, scepticism, in the sense of questioning and challenging our existing beliefs and values, is needed to combat, including in himself, the sickness associated with all incarnations of what he terms the ascetic ideal. Nietzsche recognises that dogmatic faith is not limited to religion but continues in new forms of the ascetic ideal that criticise its previous incarnations. He traces this ideal from Plato's forms, through Christianity, on into the philosophy of Kant and Schopenhauer, where the 'real' world is deified even as it is set out of reach of knowledge, and finally into science and the critics of religion who make truth their new idol (TI Fable, GM III 24). These philosophies are ascetic ideals because they all share an absolute faith in absolute value, and at the same time devalue the world at hand, ascetically denying the body, and instead nihilistically valuing an empty illusion. Even science, because of its dogmatic insistence on the value of objectivity, is a form of withdrawal from the body by virtue of its denial of the particularity of our perspectives. Hence, science 'is not the opposite of the ascetic ideal but the latter's own most recent and noble manifestation.' (GM III: 23) For Nietzsche, as for the Pyrrhonians, all forms of fanatical belief are identified as pathological. ${ }^{x v}$ The dogmatists need their idols and are unable to let go of them.

Scepticism, as Berry (2011), and before her Daniel Conway and Julie Ward, have noted (1992), ${ }^{x v i}$ is thus a prescription designed to combat the pathology of dogmatism for Nietzsche as for Sextus. What, however, is the health that the pathological is opposed to? The aim in Pyrrhonian scepticism, as we have seen, is tranquillity. Berry admits that a passive notion of tranquillity is clearly not something that Nietzsche would advocate $(2011,139)$. In her attempt to fit Nietzsche into the model of Pyrrhonism, she therefore turns to Democritus, 
suggesting that in his notion of 'cheerfulness' we find a goal for scepticism that Nietzsche would be able to embrace. Importantly, Berry here recognises that cheerfulness will have different meanings for different types, and suggests that Nietzsche's concern is that we learn a robust cheerfulness as part of a critical project that leads to health $(2011,172)$.

However, her claim that in the attainment of this cheerfulness, 'suspension of judgement, is not a means to an end; it is the end' cannot be applied to Nietzsche (Berry, 2011, 179). Firstly, as I will argue below, Nietzsche does not think such suspension is possible if this is understood as living without any beliefs or values, or adequate if it is understood less radically. Further, as an end it would not be desirable. Certainly Berry is right that Nietzsche cannot want to simply replace the fanaticism of the ascetic ideal with new beliefs that we are fanatical about and are dependent on. He does, however, call for the creation of new values as part of overcoming who we are. He demands that we 'limit ourselves to the purification of our opinions and value judgements' but also 'to the creation of tables of what is good that are new and all our own' (GS 335). In the Anti-Christ he declares that 'each one of us should devise his own virtue, his own categorical imperative.' (AC 11) While the future philosophers he calls for in Beyond Good and Evil must be 'law-givers' whose task is to 'create values' (211). Thus, for Nietzsche, scepticism is part of a radical revaluation of values and transformation in who we are. This radical aim is lost if we go too far in reducing Nietzsche's scepticism to a Pyrrhonian scepticism, and with it the character of Nietzsche's sceptical practice is also misunderstood. I will now set out how Nietzsche's experimental scepticism is a tool of transformation.

\section{$\underline{\text { Scepticism and Action }}$}

We have seen that the Pyrrhonians live by acting in accordance with natural feelings and existing laws and beliefs. In Les Sceptiques Grecs, a book that Nietzsche describes as excellent (EH Klug 3), Victor Brochard connects this practical acceptance of the precepts of the community with following common sense, claiming that:

In practice, the sage must live like everybody, he conforms to laws, to customs, to the religion of his country. He sticks to common sense, and does as others, here is the rule that following Pyrrho all the sceptics have adopted. It is by a strange irony of destiny that their doctrine is so often fought and mocked in the name of common sense; one of their principle preoccupations was in fact to not offend common sense. $(1887,59)$

This interpretation suggests an obvious tension between Pyrrhonism and Nietzsche's polemical criticisms of herd thinking and correlating praise of solitude. ${ }^{\text {vii }}$ In Beyond Good and Evil, when discussing the free spirit as a positive figure Nietzsche says: 'born, sworn, jealous friends of solitude, of our own deepest, most midnight, most midday solitude - such a type of man are we, we free spirits!' (BGE 44) These solitary free spirits contrast to Nietzsche's description in his notebooks of 'the herd animals and apostles of equality 
wrongly called 'free spirits", of whom he says 'not a single one (...) would be able to endure loneliness.' (KSA 12 3[13])

The obvious tension between Nietzsche's criticism of herd thinkers and call for solitude, and Sextus' claim that one can follow common morality and customs in practice while withholding judgement as to their value, reflects a deeper difference in their understanding of the relationship between making evaluative judgements and acting. For Nietzsche, the belief that something is of value, cannot be separated from our actions in the way that, on most readings, the Pyrrhonians seem to suggest. $\mathrm{He}$ is not claiming that we necessarily hold a conscious belief or judgement prior to acting. In acting, however, we assert that this action is worthwhile: 'life itself forces us to establish values' (TI Morality as Anti-nature: 5), 'to live man must evaluate' (KSA 11 26[118]), 'Is living not valuating, preferring, being unjust, being limited, wanting to be different?' (BGE 9), 'no people could live without first evaluating' (Z I: 15) and 'All actions may be traced back to evaluations' (D II 104). This does not always correspond to conscious assent to an evaluative proposition. Nietzsche's claim is that in choosing a course of action, in being a certain kind of person, we both express and are driven by an evaluative standpoint that is fundamental to who we are: 'Our intellect, our will likewise our feelings are dependent on our valuations: these correspond to our drives and the conditions of their existence.' (KSA 11: p.661) Without these valuations we would be incapable of action. Thus, given Nietzsche does not think it is possible to live without evaluating, a Nietzschean scepticism cannot be characterised as having no beliefs, or being totally detached.

It might seem that questioning our belief system while acting as before is exactly what the crowd in the market place, who do not understand the madman's speech when he claims we have killed God and wiped 'away the entire horizon' (GS 125), the free thinkers who still belief in altruism (KSA 12 10[170]), xviii or the failed free spirits committed to the unconditional value of truth (GM III 24), are doing. They claim to no longer believe in God yet still adhere to Christian morality. Nietzsche's claim, however, is that their actions show that they remain committed to the ascetic ideal in a new form. Thus, belief in the ascetic ideal is not truly undermined so long as we still live by it. Were we to finally give up this ideal we would face a crisis of nihilism (KSA 12 5[71]). Once our ideals have been exposed as illusions, and we no longer judge, and ultimately no longer feel, something to be true or good, we cannot live by them. Hence Nietzsche's warning that the consumption of Kant might lead to 'gnawing and disintegrating scepticism and relativism' (HH I 261).

Given Nietzsche's interest in transforming who we are, he is concerned that we question the valuations that exist at the level of our drives and condition our actions. We cannot truly question our values, and their incorporation into the kind of self we are, whilst living according to the customs or habits which instantiate them. If Frede's reading is right and Sextus does not suggest the sceptic gives up everyday beliefs (rather than beliefs about how things are in themselves), then this only shows more starkly that Pyrrhonian scepticism does not go far enough for Nietzsche. If scepticism does not question the beliefs and values we employ when we act, which underscore who are, then it is toothless 
when it comes to forging a new way of living and being. It is precisely the evaluations we live by and the beliefs that form who we are, in some cases unconsciously, that Nietzsche wants to challenge in his version of scepticism. For Nietzsche, living differently is therefore integral to scepticism itself. It is only by trying out new practices and cultivating the capacity to detach and move between different evaluative standpoints that we are able to question these standpoints.

If on the other hand contra Frede Sextus is claiming that the sceptic can live according to custom without having any beliefs, Nietzsche would maintain that sceptic demonstrates in their actions that there are still attached to the customs and laws which they follow and still asserting these values. The sceptic who claims to make no judgements and be totally detached is deluded. Again scepticism fails to be sufficiently radical for Nietzsche. Nietzsche is concerned not just to challenge our surface beliefs but to challenge our way of acting and being, and thus the judgements they instantiate.

Because genuine scepticism wrenches us from our customary way of being and common way of thinking and acting we need the ability to endure solitude. Our scepticism must work in partnership with a capacity to do without our connection with those who share the way of being and thinking that our scepticism undermines. An inability to endure loneliness implies a corresponding inability to pursue critical inquiry to the point where it threatens the beliefs that bind us to the community, and as Brochard puts it 'offends common sense'. A capacity for solitude is not only necessary to see the implications of scepticism through but the practice of solitude, involving stepping out of our customary habits, and away from the 'sociability' with which we 'deafen ourselves' (UT III 5), can help to break our attachment to our beliefs and escape the common way of living. Hence, solitude can also help develop our sceptical capacity precisely because it involves stepping out of the habitual behaviour of following customs, which for Nietzsche cannot be disentangled from holding a belief or having values.

Scepticism, is therefore necessarily experimental for Nietzsche. An association he makes both in the Gay Science and in notes from 1880 and 1885: 'I approve of any form of scepticism to which I can reply, 'Let's try it!' But I want to hear nothing more about all the things and questions which don't admit of experiment.' (GS 51); 'Scepticism! Yes, but a scepticism of experiments! Not the inertia of despair' (KSA 9 6[356]); 'Our actions are, given we are sceptics, experiments' (KSA 9 6[442]); If actions are always, as Nietzsche suggests, evaluations, then we must try out different actions in order to become detached from the beliefs and values we currently take as certain. It is not just that we use different interpretations to challenge each other, but that we can only become detached from our entrenched beliefs and value standpoints if we try out other standpoints, because total detachment is not possible. This experimental scepticism has both a destructive and creative aspect, I will consider first the former. 
It is not just our way of life but who we are that is intimately connected to what we believe. In the Nachlass, Nietzsche describes 'man as a multiplicity of "wills to power": each one with a multiplicity of means of expression and forms' (KSA 12: 1[58]). Thus, for Nietzsche there is no 'pure, will-less, painless, timeless, subject of knowledge' (GM III:12), and the self consists of contingent and unstable hierarchies of wills to power, constantly interpreting and asserting their interpretation and evaluation. On Nietzsche's hypothesis, xix in which there is no unitary 'subject' but rather a complex and fluid self that consists of a multiplicity of wills to power, where is the agency that takes up a transformative sceptical practice? Agency does not need to be stable or simple. We do not have to accept the account of agency as a doer that stands behind an action associated with the idea of the subject that Nietzsche puts into question, suggesting: "the "subject" is not something given but a fiction added on, tucked behind' (KSA 12: 7[60]). Various practices can be taken up, and shaped, by different wills to power, or groups of wills to power at different times. These wills to power form part of the changing organisation that makes up the self. The real problem then is not so much a lack of agency as an excess of it. What unites the various agencies as a self who leads one life? This unity will not be a simple or given unity, of the sort Nietzsche rejects as an illusion. Rather it is a complex, constructed and changing unity. For Nietzsche, there cannot be just one model of what will count as a unified self. There is no self that exists prior to or beyond its activity and commitments. It is these commitments and actions that establish an appearance of unity even while multiple agencies are operating.

It is our beliefs and values, or illusions as Nietzsche would allege, that form the horizons that make living a life possible: 'we have arranged for ourselves a world in which we are able to live' (GS 121). If we dismantle this world, we cannot continue to live as we currently are. It is not possible to continue our current existence without the horizons of belief it depends on. Hence, Nietzsche claims that when:

Something you formerly loved as a truth or a probability now strikes you as an error; you cast it off and believe your reason has made a victory. But maybe that error was necessary for you then, when you were still another person (GS 307).

It is because our life depends on the beliefs that form the horizons within which we act that Nietzsche sees scepticism as so dangerous, claiming that 'every great degree of caution in inferring, every sceptical disposition, is a great danger to life' (GS 111). It is also, however, precisely because of this that developing scepticism is so important for Nietzsche. The practice of scepticism opens up the possibility of transformation. Nietzsche claims 'for humans alone among the animals there are no eternal horizons and perspectives.' (GS 143) Concerning our religious and metaphysical searches, Nietzsche declares that: 'We have absolutely no need of these certainties regarding the furthest horizon to live a full and excellent human life.' (HH II VS 16) Our metaphysical need is 'a need that has come into existence 
and consequently also a transient one' (HH I 131). The sceptic can, therefore, overcome this need.

However, though he would have us overcome our attachment to morality and our need for the furthest horizons, Nietzsche, does not think we can do without all horizons. Nietzsche contends that 'A living thing can be healthy, strong and fruitful only within a horizon.' (UM II 1) It is not, therefore, a case of eradicating all beliefs and values but rather of developing a capacity to detach from them that also allows for the creation of new values. Let us turn now to the creative part of Nietzsche's project

\section{$\underline{\text { Scepticism and Engagement }}$}

Nietzsche welcomes the destruction of existing beliefs and values as a clearing of our current horizons, and with it the going-under of our current self, but he recognises the need for the creation of new values and new horizons, if a new self is to emerge. Thus, after science has 'proved that it can take such goals away and annihilate them' an 'experimenting would be in order, in which every kind of heroism could find satisfaction - an experimenting that might last for centuries.' (GS 7) Nietzsche's scepticism, therefore, is a partner to this creative experimentation. We have already seen how Nietzsche rejects the possibility of a total suspension of judgement, if this is understood to mean we affirm nothing, and thus challenging the beliefs we have previously relied on is necessarily experimental in that it cannot avoid trying out new evaluative stances.

An experimental scepticism which engages with the body also opens the way to new creation. This is why, as has been noted previously, Nietzsche contrasts his scepticism to a weak, passive scepticism of despair and withdrawal, of which he accuses Pyrrho (Bett, 2000, 78; Urs Sommer, 2006, 265; Parush, 1976, 537). Experimental scepticism, is the scepticism of strong spirits who are ready for the task of new creation, and who are not weary as Nietzsche claims Pyrrho was, writing: 'What inspired the Sceptics? Hatred against the Dogmatists - or a need for calm, a weariness as with Pyrrho.' (KSA 13 15[58])

It is important to stress that Nietzsche's version of scepticism must be opposed to those who claim objectivity or impartiality. Objectivity in this sense is merely an illusion given 'there is only a perspectival seeing, only a perspectival knowing' (GM III 12). As Berry notes, the objective men exhibit a dishonest self-denial and are incapable of owning their own perspectives $(2011,115)$. Nietzsche's scepticism in contrast must be rooted in self-awareness and accept the inescapability of perspectives.

However, Nietzsche's concern that we own our perspectives goes beyond the idea of accepting that we cannot obtain a view from nowhere. Nietzsche objects to the objective man not just for failing to acknowledge the presence of his perspectives but for failing to assert them. He is opposed to the way in which the objective man is cheerful in the sense of being untroubled by deep feeling: "he is cheerful, not because he has no troubles but because he has no fingers and facility for dealing with his troubles.' (BGE 207) He bemoans his 'perilous 
unconcernedness over Yes and No' and that such a man 'no longer knows how to affirm or deny; he does not command neither does he destroy.' (BGE 207)

Nietzsche's criticism of an ability to affirm or deny would seem then to apply not just to the objective men of his day but also to Sextus' description of the Pyrrhonian cultivation of equipollence leading to the suspension of judgement because one is 'at a loss whether to assent or deny' (PH I 7). Nietzsche's attack on the superficial cheerfulness of the objective man could also be levelled against Pyrrhonian sceptics given Sextus' claim that sceptics 'follow the observance of everyday life without holding opinions. They therefore remain without feeling in matters of opinion and with moderation of feeling in matters forced upon them' (PH III 234). As Burnyeat suggests, to live as Sextus proposes is to live without taking ownership of the principles of our actions and thus 'the withdrawal from truth and real existence becomes, in a certain sense a detachment from oneself.' $(1998,41)$

It is true that in Human All Too Human Nietzsche praises indifference, writing: 'What is now needed in regard to these things is not knowledge against faith but indifference against faith and supposed knowledge in these domains.' (HH II VS 16) This is not, however, a general indifference that Nietzsche is praising, but only indifference to the inaccessible spheres of metaphysics and religion, where we have searched for universal meaning. It is clear that Nietzsche is opposed to a version of scepticism too indifferent to be able to affirm or deny and that he sees this as form of sickness or weakness. In Beyond Good and Evil Nietzsche vehemently attacks a scepticism that comes from a weak constitution.

Against this kind of 'good will' - a will to the actual active denial of life there is today confessedly no better sedative and soporific than scepticism [...] the sceptic, that delicate creature is all too easily frightened; his conscience is schooled to wince at every No, indeed even at a hard decisive Yes, and to sense something like a sting [...] scepticism is the most spiritual expression of a certain complex physiological condition called in ordinary language nervous debility and sickness. (BGE 208)

Nietzsche's strong sceptic, on the other hand, is not moderate in feeling, rather he allows himself 'the great method for acquiring knowledge [Erkenntniss]: he feels many pros and cons' (KSA 11 26[119]), and engages with as wide a range of feelings as possible: 'We must proceed experimentally with things, be sometimes angry, sometimes affectionate toward them and allow justice, passion, and coldness toward them to follow one upon the other.' (D 432) Nietzsche's sceptic takes ownership of their feelings and learns to get control over [his] 'For and Against' (HH I Preface 6). It is a scepticism out of which one can claim to emerge 'more courageous and healthier than ever, once more in possession of [one's] instincts' (D 477).

This engagement with our 'pros and cons' is a prerequisite for creation. It is only by living in and knowing our own drives, that we will be able to find and affirm new values. It is also, as we have seen, as prerequisite for genuine scepticism, 
because it is only by engaging with the range of evaluative standpoints within us and acting differently that we can detach from the values instantiated in our habitual practices. This necessary sensualism is opposed to the philosophical pair Nietzsche couples in a late note: 'Socrates. Pyrrho. The idiosyncrasy of the philosophers against the senses.' (KSA 13 15[5])

This concern for a healthy engagement with the body in contrast to a need for withdrawal is a theme that extends beyond scepticism in Nietzsche. When Nietzsche accuses Pyrrho of décadence, he also throws Epicurus in with the set of decadent types. (KSA 13 14[99]) Nietzsche's criticisms in his late work of both the Epicureans and Stoics echo his criticisms of weak scepticism that is motivated by a need for calm, and an inability to accept and engage with one's bodily drives. When Nietzsche attacks moralities of self-control, stoicism, with its metaphor of the self as a fortress, seems to be the target. Such moralities, he alleges, cannot allow man to 'entrust himself to any instinct' and having 'turned himself into a fortress' he is 'impoverished and cut off from the most beautiful fortuities of the soul' (GS 305). The Stoics, Nietzsche proceeds in the next aphorism to claim, train themselves to be insensitive while the Epicureans avoid what they are sensitive to.

The Epicurean seeks out the situation, the persons, and even the events that suit his extremely sensitive intellectual constitution; he forgoes the rest - that is, almost everything - because it would be too strong and heavy a diet. The Stoic, by contrast, trains himself to swallow stones and worms, glass shards and scorpions without nausea, he wants his stomach to be ultimately insensible to everything the chance of existence pours into him- (GS 306).

In both cases there is an incapacity to digest, a failure to own our own passions that Nietzsche's strong experimental type is opposed to, because this incapacity deprives us of the material for experimentation in the creation of new values and the possibility of affirming and committing to these values. ${ }^{\mathrm{xx}}$

Nietzsche's praise of solitude might seem to fit with the Epicurean Garden but he comes to oppose this particular notion of withdrawal from society. The Epicurean, at least as Nietzsche chooses to represent him in his later work, withdraws selectively from what he finds difficult. Martha Nussbaum suggests that in the Garden the Epicureans have made 'an entire counter-culture that will fill every corner of daily life.' $(2009,294)$ Withdrawal to the Garden is not the painful exile that Nietzsche describes in Thus Spoke Zarathustra, where the spirit is thirsty for what it has cut itself off from, but strong enough to endure and resist drinking form the oasis that it spies:

In the yellow sands and burned by the sun he will squint thirstily at the islands rich in springs, where living beings repose beneath dark trees.

But his thirst does not persuade him to become like those comfortable creatures: for where there are oases, there are also images of idols.

( $\mathrm{Z}$ II On the Famous Wise Men) 
Rather, Nietzsche comes to portray Epicurean withdrawal as a withdrawal driven by weakness, to which we can apply his earlier criticisms of a solitude that renounces (D 440), and which therefore lacks the basis for experiment that his creative project demands.

Crucially then, experimental scepticism involves the capacity to do without certainty, and let go of beliefs, but not an incapacity for strong convictions and passions as Nietzsche, in his late work, portrays not only the Pyrrhonian sceptics but also the Epicureans and Stoics. xxi The sceptical capacity to detach must be distinguished from an incapacity to attach or engage. When Nietzsche describes the strength of a capacity for freedom from convictions in the Anti-Christ he continues:

Grand Passion, the ground and force of his being, even more enlightened, more despotic than he himself is, takes his whole intellect into its service; it makes him intrepid; it even gives him the courage for unholy means; if need be it permits him convictions, (AC 56).

Nietzsche wants us to embrace our going-under as a means to new creation. When we let go of our beliefs we experiment with new ways of valuing and new ways of being.

we are living either a preliminary or a posterior existence, depending on taste and talent, and it is best in this interregnum to be every possible extent our own reges and to found little experimental nations. We are experiments: let us also want to be such! (D 453)

\section{Conclusion}

The capacity to be our 'own reges' (D 453) and rule over ourselves, affirming our 'own categorical imperative' (AC 11), must be distinguished from holding on to principles out of a need for conviction. Nietzsche declares: 'Freedom from convictions of any kind, the capacity for an unconstrained view pertains to strength.' (AC 54) The new experimental values we assert must be something that we can affirm passionately, yet be able to let go of. This passion involves an engagement with the evaluative perspectives, or drives, within us. It requires that we be prepared to feel our pros and cons (KSA 11 26[119]). To experiment in values is to allow the hierarchy between our drives, their interaction and thus their development and character, to change. Hence, it is to allow ourselves to change. The horizons of our new selves should not become unquestionable and rigid. Nietzsche has set us the experimental task of finding a way to inhabit a given perspective and commit to values without taking them to be absolute. To be a Nietzschean sceptic one must overcome one's need for absolute ideals.

This applies even to one's commitment to scepticism. The sceptic needs to cultivate the ability to become detached from everything including their scepticism. Hence, Berry is right to emphasise that Nietzsche opposes a form of scepticism that turns into a form of dogmatism. The danger that scepticism will 
become a new attachment is one that Nietzsche is all too aware of, warning that one should even be careful not to 'cleave to one's detachment' (BGE 41).

How do we distinguish between fanaticism and this new form of commitment? Firstly, the fanatic takes the values they hold to be universal and permanent. In contrast, Nietzsche's men of the future can affirm their values as their own. This involves self-awareness. Both the fanatics' claim to have transcended the particularity of our perspectives through belief in a transcendent ideal and the Pyrrhonian claim to be able to suspend judgement all together are forms of selfdelusion. Whether a self-awareness that acknowledges the constant presence of evaluations rooted in our bodily drives and expressed in all our actions has been achieved is not something that can be identified from the outside. It is rather a question of our own intellectual conscience and a constant process of selfexamination. In addition to intellectual conscience, the right kind of commitment will involve embracing the particularlity and impermanence of our values. Therefore, the need for external values to give meaning to our actions must be overcome. We detach not just, however, from particular evaluative standpoints but from a particular self, or configuration of these standpoints. Detachment from our beliefs and values is thus also a willingness to go-under. Then it becomes possible to take 'delight' in 'self-determination' (GS 437). This joyful attitude is another hallmark of the type of commitment Nietzsche wants us to achieve. This contrasts to the weariness that Nietzsche identifies both in Pyrrhonian scepticism and in the need for faith that it superficially contrasts to, of which he says 'around all these positivistic systems hover the fumes of a certain pessimistic gloom, something of a weariness, fatalism, disappointment' (GS 347). The nature of an alternative, joyful commitment, must remain to some extent open ended, as it will be the product of an experiment which will fundamentally change us. What Nietzsche offers us is a description of the types, who fail to achieve this, not an archetype of the figure who does.

The right kind of scepticism for Nietzsche, is neither simply a stage that clears the way to the creation of new values and this new form of commitment, nor an end in itself, a new unquestionable ideal and need. We must, incorporate the sceptic's ability to do without certainty and let go of our ideals. We can then apply an experimental scepticism as an antidote to entrenched beliefs, when life needs it, just as Nietzsche argued in On the Uses and Disadvantages of History for Life that we need to know when to apply a destructive critical history (UT II). Where in this early essay Nietzsche emphasised the need to balance critical history, the late Nietzsche throws himself behind the importance of attacking the persistence of the ascetic ideal. It remains the case, however, that this sceptical attack must be rooted in life's needs. To deny the evaluative character of any actions including a sceptical attack on existing values is a form of delusion. If instead we embrace and engage with the many valuing drives within us, learning to move between them, we create the conditions for the creation of new values.

\section{References}


Ansell-Pearson, Keith. 2013. "True to the Earth: Nietzsche's Epicurean Care of Self and World." In Nietzsche's Therapeutic Teaching edited by Horst Hutter and Eli Friedland, 97-116. London. Bloomsbury.

Barnes, Jonathan. 1998. "The Beliefs of a Pyrrhonist." In The Original Sceptics: A Controversy edited by Myles Burnyeat and Michael Frede, 58-91. Indianapolis, Indiana.

Berry, Jessica N. 2011. Nietzsche and the Ancient Skeptical Tradition. New York: Oxford University Press.

Bett, Richard. 2000. "Nietzsche on the Skeptics and Nietzsche as Skeptic." Archiv für Geschichte der Philosophie 82: 62-86.

Brochard, Victor. 1887. Les Sceptiques Grecs. Paris. Imprimerie Nationale.

Burnyeat, Myles. 1998. "The Sceptic in His Place and Time." In The Original Sceptics: A Controversy edited by Myles Burnyeat and Michael Frede, 92-126. Indianapolis, Indiana.

Conway, Daniel W. and Julie K. Ward. 1992. "Physicians of the Soul: Пврıтротиं in Sextus Empiricus and Nietzsche." In Nietzsche und die Antike Philosophie edited by Daniel W. Conway and Rudolf Rehn, 193-223. Trier: Wissenschaftlicher Verlag.

Descartes, René. Selected Philosophical Writings. Translated and edited by John Cottingham, Robert Stoothoff and Dugald Murdoch. Cambridge. Cambridge University Press.

Diogenes Laertius. 1991. The Lives of Eminent Philosophers. Translated and edited by R Hicks. Cambridge MA: Harvard University Press.

Foucault, Michel. 2005. Hermeneutics of The Self; Lectures at the Collège de France 1981-1982. Translated and edited by G. Burchell. New York: Picador.

Frede, Michael. 1998. "The Sceptic's Beliefs." In The Original Sceptics: A Controversy edited by Myles Burnyeat and Michael Frede, 1-24. Indianapolis, Indiana.

Hadot, Pierre. 1995. Philosophy as a Way of Life. Malden, MA: Blackwell.

A.A. Long From Epicurus to Epictetus

Loeb, Paul. 2005. "Finding the Übermensch in Nietzsche's Genealogy of Morality.” Journal of Nietzsche Studies, 30: 70-101.

Nehamas, Alexander. 1985. Nietzsche; Life as Literature. Cambridge, Mass.; London: Harvard University Press.

2000. The Art of Living; Socratic Reflections from

Plato to Foucualt. Berkeley and Los Angeles, California; London: University of California Press.

Nussbaum, Martha C. 2009. The Therapy of Desire: Theory and Practice in Hellenistic Ethics. Princeton, N.J. ; Woodstock: Princeton University Press.

Parush, Adi. 1976. "Nietzsche on the Skeptic's Life." The Review of Metaphysics, 29: 523-542.

Reginster, Bernard. 2003. "What is a Free Spirit? Nietzsche on Fanaticism." Archive fur Geschichte Der Philosophie, 85,1: 51-85.

Urs Sommer, Andreas. 2006. "Nihilism and Skepticism in Nietzsche." In Companion to Nietzsche, edited by Keith Ansell-Pearson, 148-167. Oxford: Blackwell, 2006.

Sextus Empiricus. 2000. Outlines of Scepticism. Translated and edited by Julia Annas and Jonathan Barnes. Cambridge: Cambridge University Press. 
Vogt, Katja. 2012, "Appearances and Assent: Skeptical Belief Reconsidered." Classical Quarterly 62: 648-663.

Ure, Michael. 2008. Nietzsche's Therapy: Self-cultivation in the Middle Works. Lanham, MD: Lexington Books.

ii Neither Hadot or Foucault are setting out to develop a detailed analysis of Nietzsche's thought based on this insight. Nehamas offers an interpretation of Nietzsche's thought as an art of living that employs a literary model (1985). Nehamas' important work does not address the role of scepticism, which is my focus here, and more generally does not explain what techniques allow the modern man to become emancipated from current conditions before his is able to give style to his character.

ii Nietzsche citations are made using the following abbreviations, with section number or title where applicable and aphorism number indicated: The Untimely Meditations (UT), Human, all Too Human (HH), Daybreak (D), The Gay Science (GS), Thus Spoke Zarathustra (Z), On the Genealogy of Morality (GM), Beyond Good and Evil (BGE), Twilight of the Idols (TI), The Anti-Christ (AC), Ecce Homo (EH), Kritische Studienausgabe von Giorgio Colli und Mazzino Montinari (KSA). Translations used are listed in the references.

iii The importance of the Overman in Nietzsche's thought does not rest on Thus Spoke Zarathustra Alone. In On the Genealogy of Morality, Nietzsche refers to the 'man of the future', who can overcome nihilism, as a 'bell-stroke of noon' who 'gives back to earth its goal' (GM II: 24) which clearly connects this figure to overman of 'the great noontide of earth and man' (Z III: 13, 2) who is 'the sense of the earth' (Z Prologue: 3). Paul Loeb has also argued that the second essay of On the Genealogy of Morality can only be understood in the context of Nietzsche's philosophy of the Übermensch (2005).

iv For example KSA (7 31[10], 32[76])

v Nietzsche read the first volume of Friedrich Überweg's Grundriss der Geschichte der Philosophie von Thales bis auf die Gegenwart, in 1865, and E Zeller's Die Philosophie der Griechen in inhrer geschichtlichen Entwicklung dargestellt in 1867 (Brobjer, 2008, 257-258), both of which contain discussions of Sextus Empiricus. ${ }^{v i}$ Citations from Outlines to Scepticism are cited with the abbreviation $\mathrm{PH}$, book number and Fabrician section numbers.

vii Citations from The Lives of Eminent Philosophers are cited using the abbreviation DL, book number and section number.

viii Burnyeat sums up his objections to Frede's reading in the following: 'I do not think that one solitary reference to the sciences (for it is not repeated elsewhere in Sextus) in a definition borrowed from someone else is sufficient basis to credit Sextus with a distinction between dogmatic and non-dogmatic belief. It is not sufficient even when we add to the scales that Sextus frequently restricts what he suspends judgement about to the question how things are "in nature" (pros tèn phusin etc., PH I 59,78,87, et al.) or how things are "so far as concerns what the dogmatists say about them" (PH II 26, 104, III 13, 39, 135, $M$ VIII 3) or, ambiguously, how things are "so far as this is a matter for logos (statement definition, reason)" (PH I 20, 215). Just how restrictive these qualifications are 
depends on what they are contrasted with, and in every case the contrast is with how things appear, where this, as we have seen, is to be taken non-epistemically. All we are left with, then, is a passive impression (phantasia) or experience (pathos), expressed in a statement which makes no truth-claim about what is the case.' $(1998,51)$ Barnes argument is that given it is clear that the sceptic rejects all philosophical or theoretical tenets, the sceptic can have no theory of truth. They cannot then make ordinary judgements that something is the case, such as the water is hot, as this depends on a criterion of truth $(1998,78)$. More recently Vogt has argued that in this passage Sextus is concerned with whether the sceptic has any teachings: "The question of whether the sceptic dogmatizes leads Sextus to discuss whether central pieces of sceptical philosophy - the sceptical formulae - are doctrinal teachings. This assessment fits well with the way in which Sextus, quite generally, keeps doxa and dogma apart, using these words and their cognates in different contexts: dogmatikôs when he refers to philosophical claims, and adoxastôs when he describes the sceptic's life [...] Sextus says that there is a general sense of 'dogma' - a kind of acquiescing - that figures in the sceptic's life. As I see it, this is how the formulae (and other thoughts central to the sceptic's philosophy) can linger in the sceptic's mind, without her having accepted them as true.' $(2012,656)$ She suggests further that if Sextus follows the understanding of belief that is used by his opponents, the Stoics and Epicureans, then we can take his claim that sceptics do not posit or reject anything, and thus make no judgements, to mean they have no beliefs (Vogt, 2012, 654).

ix For the history of the claim that we cannot live without belief see Burnyeat $(1998,27, \mathrm{n} 4)$.

x Appearance for Sextus refers to impressions and generally includes not just sense impressions but also objects of thought. (Burnyeat, 1998, 38, Vogt, 2012, 659)

xi Here whether no belief is involved, in 'assenting without opinion' to what 'everyday life' 'finds convincing' seems more controversial (PH II 102) it sounds like, when we take smoke to indicate fire and divert our route accordingly, we may have a belief based in experience. Barnes suggests there could be an account that does not rely on inference, and thus belief, but notes Sextus does not give it (1998, 87-88). Here the notion of habit, which Diogenes Laertius refers to, could be taken to be what allows us to connect the smoke and fire and act accordingly. If, however, belief is involved in our use of signs, this still leaves many beliefs, including normative beliefs, which the sceptic has to explain how we can do without when acting.

xii Translation altered

xiii Descartes is of course concerned not simply with abstract conditions of knowledge but with the experience of doubt, but the aim of an individual taking up the method of doubt is to arrive at solid foundations for knowledge. As he writes in the First Meditation: 'I realized that it was necessary, once in the course of life, to demolish everything completely and start again right from the foundations if I wanted to establish anything at all in the sciences that was stable and likely to last.' $(1988,76)$ 
xiv Michael Ure and Keith Ansell-Pearson have both explored Nietzsche's philosophy in terms of a therapeutic practice (Ansell-Pearson, 2013, 97; Ure, 2008)

xv Bernard Reginster highlights Nietzsche's opposition to fanaticism, considering it in the context of his ideal of the free spirit. Reginster argues that Nietzsche ceases to see a commitment to truth as definitive of the free spirit because, as he expresses in GM III, 24, he comes to recognise this commitment as itself a form of fanaticism (2003). I consider GM III, 24, to indicate rather Nietzsche's awareness of the tension between the need to pursue enquiry without any limitation on where it will take us and the inevitability of presuppositions, including the value of such enquiry. However, as I have argued elsewhere, he does not give up on the goal of navigating this tension as part of a free spirited pursuit of truth, even if he comes to hold that it has not yet been successfully navigated and thus that the right kind of free spirits have not yet emerged (----).

xvi Conway and Ward argue that both Nietzsche and Sextus use self-refutation as a deliberate therapeutic practice, operating from within the dogmatic paradigm (1992, 193-4).

xvii It is true that Nietzsche makes a seemingly positive claim in the context of his reference to Brochard that the sceptics were honourable. As with Christ, who Nietzsche also praises in his late work, because he practiced his life according to his own instinct, as 'consequences of one instinct' (AC 33), Nietzsche can admire the sceptics and still use them as an important counterpoint to the type that he hopes will emerge. Nietzsche may be praising the ancient sceptics here because they put into practice their theories, but as with Christ, he can maintain that this practice expresses a decadent nature, and is thus the wrong kind of scepticism. xviii 'the mild and lily-livered concept 'humanity' à la Comte and after Stuart Mill [...] Is once again the cult of Christian morality under a new name... the freethinkers, e.g. Guyau' (KSA 12: 10[170])

xix In the context of Nietzsche's sceptical attitude his view of the self must be taken as a hypothesis he is trying out and as open to revision. I discuss the problem of how we can know the activity of unconscious and multiple drives in ------- and explore the broader question of the status of Nietzsche's hypothesis of the will to power in the context of his perspectivism in-

xx Keith Ansell-Pearson argues that in his middle work Nietzsche admires Epicurus for letting his passions grow modest, rather than seeing him as indifferent to passions $(2013,100-101)$

xxi Conway and Ward argue that Sextus' attitude to the passions contrasts to the Stoics precisely because he takes passions to be essential to life $(1992,213)$. The Pyrrhonian passive approach to the passions, however, in which they move one without being affirmed, or felt strongly, is still open to the accusation that they do not own and fully engage with drives and thus will not be able to experiment with new values as Nietzsche's project requires. 